\title{
PENGARUH PENDAPATAN ASLI DAERAH, DANA ALOKASI UMUM DAN DANA ALOKASI KHUSUS TERHADAP BELANJA MODAL (PADA PEMERINTAH PROVINSI BANTEN PERIODE 2011-2015)
}

\author{
Arry Eksandy ${ }^{1}$ \\ *Prodi Akuntansi, Fakultas Ekonomi dan Bisnis, Universitas Muhammadiyah Tangerang \\ *arry_eksandy@umt.ac.id ${ }^{1}$ \\ Mohamad Zulman Hakim ${ }^{2}$ \\ *Prodi Akuntansi, Fakultas Ekonomi dan Bisnis, Universitas Muhammadiyah Tangerang \\ *zulman.hakim@umt.ac.id ${ }^{2}$ \\ Ekawati $^{3}$ \\ *Prodi Akuntansi, Fakultas Ekonomi dan Bisnis, Universitas Muhammadiyah Tangerang \\ *ekawwwatiii@yahoo.com ${ }^{3}$
}

\begin{abstract}
The purpose of this research is to know the effect of Local Revenue, General Allocation Fund, Special Allocation Fund to Capital Expenditure. The research period used is 5 years in the period 20112015.

The study population covers all the existing Kota / Kabupaten in Banten Province for the period of 2011-2015. Sampling technique using saturated sampling technique. Based on the predetermined criteria, the number of samples 8 Kota and 8 Kabupaten. The type of data used is secondary data obtained from the official website of Banten Province. Data analysis method used is panel data regression analysis.

The results of this study indicate that the General Allocation Fund affects the Capital Expenditure, while the Original Revenue and Special Allocation Fund has no effect on Capital Expenditure.
\end{abstract}

Keywords: Local Revenue, General Allocation Funds, Special Allocation Funds, Capital Expenditures

\section{PENDAHULUAN}

Peraturan Pemerintah (PP) Nomor 58 Tahun 2005 memberikan penegasan bahwa daerah memiliki kewenangan untuk menentukan alokasi sumber daya ke dalam Belanja Modal dengan menganut asas kepatutan, kebutuhan dan kemampuan daerah. Sebelum mewujudkan pelayanan kepada publik, pemerintah daerah terlebih dahulu menyusun alokasi dan realisasi pada APBD. APBD diartikan sebagai daftar terperinci mengenai pendapatan dan pengeluaran daerah dalam waktu satu tahun. Menurut UU No. 33 Tahun 2004 Pasal 157 menyatakan bahwa salah satu pendapatan daerah adalah Dana Perimbangan yang terdiri dari Dana Bagi Hasil (DBH), Dana Alokasi Umum (DAU), Dana Alokasi Khusus (DAK).

Kondisi perekonomian Provinsi Banten dalam tingkat kota memiliki perbedaan, sebagai contoh tiga kota itu antara lain kota Serang, kota Tangerang Selatan dan kota Cilegon. Dilihat dari berdirinya tiga kota ini kota Serang merupakan yang terlebih dahulu dari kota Tangerang Selatan dan kota Cilegon, bahkan menjadi ibu kota provinsi namun secara pertumbuhan ekonominya kota Serang adalah yang paling rendah. Menurut Halim (2009), permasalahan yang dihadapi daerah pada umumnya berkaitan dengan penggalian 
sumber-sumber pajak dan retribusi daerah yang merupakan salah satu komponen dari Pendapatan Asli Daerah (PAD) masih belum memberikan kontribusi signifikan terhadap penerimaan daerah secara menyeluruh.

Setiap daerah mempunyai kemampuan yang tidak sama dalam mendanai kegiatan operasional didaerahnya masing-masing, hal tersebut menimbulkan ketimpangan fiskal antar daerah. Untuk mengatasi ketimpangan tersebut, Pemerintah pusat mentransfer dana perimbangan untuk masing-masing daerah. Salah satu dana perimbangan yaitu Dana Alokasi Umum (DAU), Dana Alokasi Umum merupakan dana yang berasal dari pemerintah pusat yang diambil dari APBN yang dialokasikan dengan tujuan pemerataan keuangan antar daerah untuk membiayai kebutuhan pengeluaran pemerintah daerah dalam rangka pelaksanaan desentralisasi.

Sebagai contoh Kabupaten Serang dan Kabupaten Tangerang dengan Kota Serang dan Kota Tangerang, karena Kabupaten Serang merupakan daerah lama jika dibandingakan oleh Kota Tangerang maka pemerintah daerah pun memberikan Dana Alokasi Umum (DAU) lebih besar untuk pengembangan daerah.

Namun untuk kota Serang yang mana sebagai ibu kota provinsi ini, dalam pemberian DAU terendah dibandingkan daerah yang lain, sedangkan kota Tangerang yang sudah jauh berkembang dibandingkan kota Serang mendapatkan alokasi DAU dua kali lipat dari yang didapatkan oleh kota Serang. Hal ini akan berdampak juga pada pertumbuhan kota tersebut sehingga tidak bisa maksimal dalam memberdayakan daerah ini.

Dengan demikian, terjadi transfer yang cukup signifikan didalam APBN dari pemerintah pusat ke pemerintah daerah. Dalam beberapa tahun berjalan, proporsi Dana Alokasi Umum terhadap penerimaan daerah masih yang tertinggi dibanding dengan penerimaan daerah yang lain, (Andi Gustiani, 2014).

Dana transfer dari pemerintah pusat ke pemerintah daerah selain DAU adalah Dana
Alokasi Khusus (DAK). Berdasarkan Undangundang No. 33 Tahun 2004, Dana Alokasi Khusus merupakan dana yang bersumber dari APBN yang dialokasikan kepada daerah tertentu dengan tujuan untuk membantu mendanai kegiatan khusus yang merupakan urusan daerah dan sesuai dengan prioritas nasional. Pemanfaatan DAK diarahkan pada kegiatan investasi pembangunan, pengadaan, peningkatan, dan perbaikan sarana dan prasarana fisik dengan umur ekonomis yang panjang, tetapi dana DAK justru belum meluas ke daerah-daerah tertinggal, terluar, terpencil serta yang kapasitas pemerintahannya belum memadai dalam memberikan fungsi pelayanan public, (Isti Peramatasari, 2016). Dengan adanya pengalokasian DAK dapat mempengaruhi belanja modal, karena DAK cenderung akan menambah aset tetap yang dimiliki pemerintah guna meningkatkan pelayanan publik.

Pada Undang-undang Nomor 32 Tahun 2004 disebutkan bahwa salah satu sumber pendapatan daerah adalah Pendapatan Asli Daerah (PAD) yang terdiri dari hasil pajak daerah, hasil retribusi daerah, hasil pengelolaan kekayaan daerah yang dipisahkan, dan lain-lain PAD yang sah. Ida Bagus Dwi Putra (2015) menyebutkan bahwa permasalahan yang terjadi saat ini, pemerintah daerah terlalu menggantungkan transfer tidak bersyarat dari pemerintah pusat untuk membiayai belanja modal dan pembangunan tanpa mengoptimalkan pendapatan asli daerah yang dimiliki daerah tersebut, sehingga akan mengakibatkan pemborosan dalam belanja modal. Transfer tak bersyarat juga mengakibatkan peningkatan pengeluaran publik melebihi kenaikan pendapatan masyarakatnya. Permasalahan yang muncul akibat ketergantungan pemerintah daerah kepada dana hibah dari pemerintah pusat tersebut dinamakan fenomena flypaper effect.

Belanja Modal merupakan pengeluaran anggaran yang digunakan untuk perolehan aset tetap dan aset lainnya yang memberi manfaat lebih dari satu periode akuntansi (PP No. 24 Tahun 2005). Modal sangat berkaitan dengan perencanaan keuangan jangka panjang, terutama 
pembiayaan untuk pemeliharaan aset tetap yang dihasilkan dari Belanja Modal tersebut. Belanja Modal harus memperhatikan kemanfaatan (usefulness) dan kemampuan keuangan pemerintah daerah (budget capability) dalam pengelolaan aset tersebut dalam jangka panjang (Wimpi Priambudi, 2016).

Diberlakukannya otonomi daerah memberikan kesempatan pemerintah daerah untuk lebih mengembangkan potensi daerah. Untuk mengembangkan potensi daerah tersebut maka pemerintah daerah perlu meningkatkan anggaran belanja modal, Sumber-sumber dana yang digunakan untuk membiayai belanja modal tersebut terdiri dari Pendapatan Asli Daerah (PAD), Dana AlokasiUmum (DAU) dan Dana Alokasi Khusus (DAK).

\section{KAJIAN PUSTAKA DAN PENGEMBANGAN HIPOTESIS}

\section{Teori Stewardship (Grand Theory)}

Teori ini menggambarkan tentang adanya hubungan yang kuat antara kepuasan dan kesuksesan organisasi. Pemerintah selaku steward dengan fungsi pengelolaan sumber daya dan rakyat selaku principal pemilik sumber daya. Terjadi kesepakakatan yang terjalin antara pemerintah (Steward) dan rakyat (Principal) berdasarkan kepercayaan, kolektif sesuai tujuan organisasi. Organisasi sector public memiliki tujuan memberikan pelayanan kepada public dan dapat dipertanggung jawabkan kepada public. Sehingga dapat diterapkan dalam model kasus organisasi sector public dengan teori stewardship.

Teori stewardship mengasumsikan hubungan yang kuat antara kesuksesan organisasi dengan kepuasan pemilik. Pemerintah akan berusaha maksimal dalam menjalankan pemerintahan untuk mencapai tujuan pemerintah yaitu meningkatkan kesejahteraan rakyat. Apabila tujuan ini mampu tercapai oleh pemerintah maka rakyat selaku pemilik akan merasa puas dengan kinerja pemerintah. Table dibawah ini mengenai asumsi dasar teori Stewardship.

\section{Teori Stakeholder (Grand Theory)}

Selain teori Stewardship, teori lain yang mendasari penelitian ini ialah teori Stakeholder. Istilah Stakeholder pertama kali diperkenalkan oleh Standford Research Institute (RSI) pada tahun 1963 (Freeman, 1984). Freeman (1984) mendifinisikan Stakeholder merupakan kelompok maupun individu yang dapat mempengaruhi atau dipengaruhi oleh proses pecapaian tujuan organisasi. Stakeholder theory merupakan sekelompok orang, komunitas atau masyarakat baik secara keseluruhan maupun parsial yang memiliki hubungan serta kepentingan terhadap organisasi (Putro, 2013). Dalam organisasi sector public, sector public memiliki cakupan yang lebih luas dan lebih beragam.

Keberhasilan dalam organisasi public maupun swasta ialah sejauh mana organisasi tersebut dapat menjamin kepuasan Stakeholder utama (Masyarakat Sebagai Stakeholder Utama). Teori stakeholder mengansumsi hubungan Pemerintah selaku pemegang kekuasan dalam roda pemerintahan harus menekankan aspek kepentingan rakyat selaku Stakeholder (Putro, 2013), Putro juga menekankan pemerintah harus mampu mengelola kekayaan daerah, pendapatan daerah serta yang berupa asset daerah untuk mensejahterakan rakyat sesuai dengan isi dari Undang-Undang Dasar 1945 pasal 33 yang menyatakan bahwa seluruh kekayaan alam yang dikuasai pemerintah harus digunakan dan dimanfaatkan untuk kesejahteraan rakyat.

\section{Peran Belanja Modal}

Pada Lampiran Peraturan Menteri Keuangan Nomor 91/PMK.05/2007 Tentang Bagan Akun Standar menyebutkan Belanja Modal merupakan pengeluaran anggaran yang digunakan dalam rangka memperoleh atau menambah aset tetap dan aset lainnya yang memberi manfaat lebih dari satu periode akuntansi serta melebihi batasan minimal kapitalisasi aset tetap atau aset lainnya yang ditetapkan oleh pemerintah. Aset tetap tersebut dipergunakan untuk operasional kegiatan sehari-hari suatu satuan kerja bukan untuk dijual. 
Menurut Abdul Halim (2007:101) "Belanja modal merupakan pengeluaran anggaran untuk perolehan aset tetap dan aset lainnya yang memberi manfaat lebih dari satu periode akuntansi". Menurut Mardiasmo (2002:67) "Belanja Modal adalah pengeluaran yang manfaatnya cenderung melebihi satu tahun anggaran dan akan menambah anggaran rutin untuk biaya operasional dan pemeliharaannya".

Belanja Modal dilakukan dalam rangka pembentukan modal yang sifatnya menambah aset tetap atau aset lainnya yang memberikan manfaat lebih dari satu periode akuntansi, termasuk di dalamnya adalah pengeluaran untuk biaya pemeliharaan yang sifatnya mempertahankan atau menambah masa manfaat, meningkatkan kapasitas dan kualitas aset. Sebagaimana dimaksud dalam Peraturan Menteri Dalam Negeri Nomor 13 tahun 2006 tentang Pedoman Pengelolaan Keuangan Daerah Pasal 53 menyatakan bahwa Belanja Modal digunakan untuk pengeluaran yang dilakukan dalam rangka pembelian/pengadaan atau pembangunan aset tetap berwujud yang mempunyai nilai manfaat lebih dari 12 (dua belas) bulan.

Dalam kegiatan pemerintahan, seperti dalam bentuk tanah, peralatan dan mesin, gedung dan bangunan, jalan, irigasi dan jaringan, dan aset tetap lainnya. Nilai pembelian / pengadaan atau pembangunan aset tetap berwujud yang dianggarkan dalam Belanja Modal hanya sebesar harga beli/bangun aset. Aset tetap yang dimiliki sebagai akibat adanya Belanja Modal merupakan prasyarat utama pemerintah daerah dalam memberikan pelayanan publik.

Anggaran Belanja Modal dalam APBD untuk menambah asset tetap. Anggaran belanja Modal ini didasarkan pada kebutuhan akan sarana dan prasarana, baik untuk kelancaran pelaksanaan tugas pemerintah maupun untuk fasilitas public. Setiap tahun biasanya dilaksanakan pengadaan asset tetep oleh pemerintah daerah sesuai dengan prioritas anggaran dan pelayanan public yang memberikan dampak jangka panjang secara financial.

\section{Pengembangan Hipotesis}

\section{a. Pendapatan Asli Daearah Terhadap Belanja Modal}

Menurut Mardianso (2002: 132), Pendapatan Asi Daerah adalah penerimaan daerah dari sektor pajak daerah, retribusi daerah, hasil perusahaan milik daerah, hasil pengelolaan kekayaan daerah yang dipisahkan, dan lain-lain Pendapatan Asli Daerah yang sah. Belanja Modal adalah pengeluaran anggaran untuk perolehan aset tetap dan aset lainnya yang memberi manfaat lebih dari satu periode akuntansi, Belanja Modal meliputi antara lain belanja modal untuk perolehan tanah, gedung, dan bangunan, peralatan dan aset tak berwujud (Wimpi Priambudi, 2016)

\section{H1: Pendapatan Asli Daerah berpengaruh positif terhadap Belanja Modal}

\section{b. Dana Alokasi Umum Terhadap Belanja Modal \\ Dana Alokasi Umum adalah dana yang} berasal dari APBN yang dialokasikan dengan tujuan untuk pemerataan keuangan antar daerah untuk membiayai kebutuhan pengeluaran dalam rangka pelaksanaan desentralisasi. Dana perimbangan keuangan merupakan konsekuensi adanya penyerahan kewenangan pemerintah pusat kepada pemerintah daerah. Dengan demikian, terjadi transfer yang cukup signifikan dalam APBN dari pemerintah pusat ke pemerintah daerah. Pemerintah daerah dapat menggunakan dana perimbangan keuangan (DAU) untuk memberikan pelayanan kepada publik yang direalisasikan melalui belanja modal (Solikin, 2010 dalam Pungky Ardani 2011).

\section{$\mathrm{H}_{2}$ : Dana Alokasi Umum berpengaruh positif terhadap Belanja Modal.}

\section{c. Dana Alokasi Khusus Terhadap Belanja Modal \\ Dana perimbangan merupakan perwujudan} hubungan keuangan antara pemerintah pusat dengan daerah. Salah satu dana perimbangan adalah Dana Alokasi Khusus, DAK merupakan dana yang bersumber dari APBN yang dialokasikan kepada pemerintah daerah untuk 
membiayai kegiatan khusus yang merupakan urusan daerah dari prioritas nasional. Tujuan DAK untuk mengurangi beban biaya kegiatan khusus yang harus ditanggung oleh pemerintah daerah pemanfaatan DAK diarahkan kepada kegiatan investasi pembangunan, pengadaan, peningkatan, perbaikan sarana dan prasarana fisik pelayan public dengan umur ekonomis panjang dengan diarahkannya pemanfaatan DAK untuk kegiatan tersebut diharapkan dapat meningkatkan pelayan public yang terealisasikan dalan belanja modal.

\section{H3: Dana Alokasi Khusus Berpengaruh positif terhadap Belanja Modal}

\section{METODE PENELITIAN}

\section{Populasi dan Sampel}

Populasi dalam penelitian ini adalah seluruh Kota/Kabupaten yang berada di Provinsi Banten dalam periode 2011-2015. Jumlah populasi dalam penelitian ini adalah 8 kota 8 Kabupaten. Pengambilan sampel yang dilakukan dengan metode sampling jenuh.

\section{Definisi dan Pengukuran Variabel}

\section{a. Variabel Independen}

Dalam penelitian ini terdapat 3 (tiga) variabel independen (bebas), yaitu:

\section{1) Pendapatan Asli Daerah}

Pendapatan Asli Daerah terdiri dari pajak daerah, retribusi daerah, hasil pengelolaan kekayaan daerah yang dipisahkan, dan lain-lain

PAD = Pajak Daerah + Retribusi Daerah + Hasil Pengelolaan Kekayaan Daerah yang Dipisahkan + Lainlain PAD yang Sah

Sumber: Pungky Ardhani (2011)

\section{2) Dana Alokasi Umum}

Dana Alokasi Umum merupakan dana transfer dari pemerintah pusat yang berasal dari Anggaran Pendapatan Belanja Negara (APBN) dan dialokasikan ke setiap daerah dalam pelaksanaan desentralisasi dengan tujuan pemerataan keuangan antar daerah untuk membiayai kebutuhan pengeluaran dan belanja pada daerah.

$$
D A U=C F+A D
$$

Sumber: Pungky Ardhani (2011)

Ket:

DAU $\quad=$ Dana Alokasi Umum

$\mathrm{CF} \quad=$ Celah Fiskal

Dimana,

Celah Fiskal $=$ Kebutuhan Fiskal -

Kapasitas fiskal

Keb. Fiskal = Total Belanja

Kap. Fiskal $=$ PAD + DBH pajak + DBH

SDA

$\mathrm{AD}=$ Alokasi Dasar

Alokasi Dasar $=90 \% \times 25 \% \times$ PDN $x$ bobot

Kabupaten/Kota atau, gaji

PNSD termasuk kenaikan gaji

pokok dan gaji ke-13 dan gaji

CPNSD.

\section{3) Dana Alokasi Khusus}

Menurut UU No. 33 Tahun 2004, Dana Alokasi Khusus (DAK) adalah dana yang bersumber dari pendapatan APBN yang dialokasikan ke daerah tertentu dengan tujuan membantu mendanai kegiatan khusus yang merupakan urusan daerah sesuai dengan prioritas nasional.

Pasal 54 ayat (2) peraturan pemerintah (PP) Nomor 55/2005 "Penentuan besaran Alokasi Dana Alokasi Khusus (DAK) masing-masing daerah". Rata-rata nasional kemampuan keuangan daerah dirumuskan sebagai berikut:

$$
\begin{aligned}
& K K D=P U-B P D \\
& P U=P A D+D A U+(D B H-D B H R D)
\end{aligned}
$$

Sumber: Pungky Ardhani (2011)

\section{Keterangan :}

KKD = Kemampuan Keuangan Daerah

PU = Penerimaan Umum APBD

BPD = Belanja Pegawai Daerah

PAD = Pendapatan Asli Daerah

DAU = Dana Aalokasi Umum

$\mathrm{DBH}=$ Dana Bagi Hasil

DBHDR $=$ Dana Bagi Hasil Dana Reboisasi 


\section{b. Variabel Dependen}

Variabel dependen yang digunakan dalam penelitian ini adalah sebagai berikut:

\section{Belanja Modal}

Belanja Modal merupakan pengeluaran anggaran yang digunakan dalam rangka memperoleh atau menambah aset tetap dan aset lainnya yang memberi manfaat lebih dari satu periode akuntansi serta melebihi batasan minimal kapitalisasi aset tetap atau aset lainnya yang ditetapkan oleh pemerintah. Aset tetap tersebut dipergunakan untuk operasional kegiatan seharihari suatu satuan kerja bukan untuk dijual. (Peraturan Menteri Keuangan Nomor 91/PMK.05/2007).

Belanja Modal $=$ Belanja Tanah + Belanja Peralatan dan Mesin + Belanja Gedung dan Bangunan + Belanja Jalan, Irigrasi, dan Jaringan + Belanja Aset Tetap Lainnya

\section{Teknik Analisis Data}

Dalam penelitian ini, teknik analisis data yang digunakan adalah analisis regresi data panel dengan bantuan sofware pengolah data statistik yaitu Eviews 9.0 Model regresi data panel dapat ditulis sebagai berikut (Winarno, 2015: 4.1):

$\mathrm{Y}=\beta_{0}+\beta_{1} X 1_{i t}+\beta_{2}$
Keterangan:
$\mathrm{Y}=$ Belanja Modal
$\beta_{0}=$ Konstanta
$X 1_{i t}=$ PAD
$X 2_{i t}=$ DAU
$X 3_{i t}=D A K$
$e_{i t}=$ Eror Term

\section{HASIL DAN PEMBAHASAN}

\section{Analisis Statistik Deskriptif}

\begin{tabular}{|c|c|c|c|c|}
\hline & BM & PAD & DAU & DAK \\
\hline Mean & 0.548750 & 0.474250 & 3.036750 & 0.116250 \\
\hline Mec & 0.245000 & 0.345000 & 0.115000 & 0.110000 \\
\hline ium & 000 & 2.20 & 66 & 0.8 \\
\hline $\mathrm{Mi}$ & 0.020000 & -0.430000 & -0.990000 & -0.900000 \\
\hline St & 1.082296 & 0.513614 & 11.89538 & 0.213850 \\
\hline ness & 4.98 & 1.756276 & 9738 & $\begin{array}{r}-1.825261 \\
1.31500\end{array}$ \\
\hline & & & & \\
\hline $\begin{array}{l}\text { Jarque-Bera } \\
\text { Probability }\end{array}$ & $\begin{array}{l}1302.754 \\
0.000000\end{array}$ & $\begin{array}{l}40.83888 \\
0.000000\end{array}$ & $\begin{array}{l}788.6012 \\
0.000000\end{array}$ & $\begin{array}{l}317.7366 \\
0.000000\end{array}$ \\
\hline Sum & 21.9 & 18.9 & 12 & 4.650 \\
\hline Sum Sq. Dev. & 45.68324 & 10.28818 & 5518.503 & 1.783538 \\
\hline Observations & 40 & 40 & 40 & 40 \\
\hline
\end{tabular}

a. Mean adalah nilai rata-rata suatu kelompok data atau teknik penjelasan kelompok yang didasarkan atas nilai rata-rata dari kelompok tersebut. mean terbesar dihasilkan oleh Dana Alokasi Umum (DAU) sebesar 3.036750 yang dimiliki oleh Kab. Tangerang Pada tahun 2014. Sementara mean terkecil sebesar 0.116250 yang dihasilkan oleh DAK yang dimiliki oleh Kota Cilegon pada tahun 2014. Sementara itu mean dari variabel lain yaitu PAD sebesar 0.474250 dan Belanja Modal (BM) sebesar 0.548750 .

b. Median adalah nilai tengah atau nilai yang letaknya ditengah dari data yang telah diurutkan dari nilai terkecil sampai terbesar. Median terbesar dihasilkan oleh PAD sebesar 0.345000 yang dimiliki oleh Kab. Tangerang pada tahun 2015. Sementara median terkecil sebesar 0.110000 yang dihasilkan oleh DAK yang dimiliki oleh Kota Cilegon pada tahun 2014. Sementara itu mean dari variabel lain yaitu DAU sebesar 0.115000 dan Belanja Modal (BM) sebesar 0.245000

c. Maximum adalah nilai terbesar dalam sebuah kelompok data. Maximum terbesar dihasilkan oleh DAU sebesar 66.70000 yang dimiliki oleh Kab.Tangerang pada tahun 2014. Sementara maximum terkecil sebesar 0.800000 yang dihasilkan oleh DAK yang dimilki oleh Kota Cilegon pada tahun 2014. Sementara itu maximum dari variabel lainnya yaitu PAD sebesar 2.200000 dan Belanja Modal (BM) sebesar 6.790000.

d. Minimum nilai terkecil dalam sebuah kelompok data. Minimum terbesar terbesar dihasilkan oleh BM sebesar 0.020000 yang dimiliki oleh Kab. Tangerang pada tahun 2015. Sementara Minimum terkecil sebesar 0.430000 yang dihasilkan oleh PAD yang dimiliki oleh Kota Serang pada tahun 2011. Sementara itu minimum dan variabel lainnya yaitu DAK sebesar -0.9000000 dan DAU sebesar -0.990000 .

e. Standar deviasi adalah ukuran dispersi atau penyebaran data. Nilai standar deviasi terbesar dimiliki oleh variabel DAU yaitu sebesar 5518.503 yang berarti bahwa variabel DAU memiliki resiko yang lebih tinggi 
dibandingkan dengan variabel-variabel yang lain. Sementara variabel DAK mempunyai tingkat resiko yang paling rendah. yaitu sebesar 1.783538. Hal ini menunjukan bahwa DAK selama periode penelitian mengalami perubahan yang tidak terlalu fluktuatif.

\section{Pemilihan Model Regresi Data Panel}

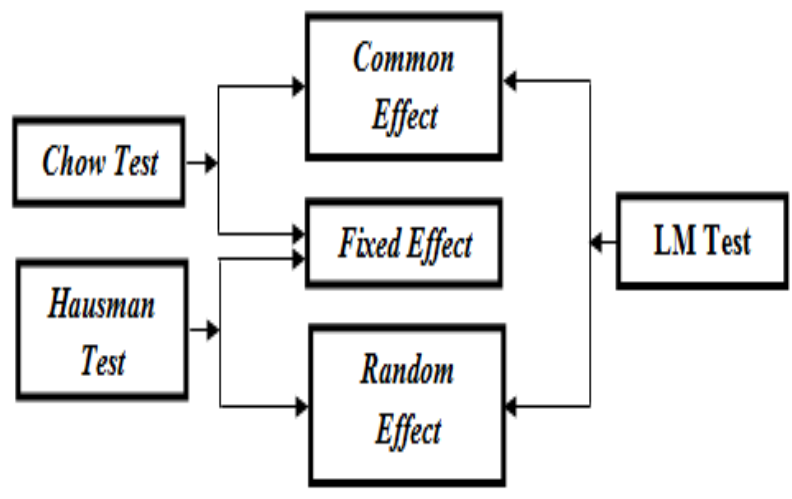

\section{a. Chow Test}

Skema Pemilihan Model Regresi Data Panel

Hipotesis dalam Chow Test adalah sebagai berikut: $\mathrm{H}_{0}$ : Model mengikuti common effect

$\mathrm{H}_{1}$ : Model mengikuti fixed effect

\begin{tabular}{|llll|}
\hline $\begin{array}{l}\text { Redundant Fixed Effects Tests } \\
\text { Equation: Untitled } \\
\text { Test cross-section fixed effects }\end{array}$ & & & \\
\hline \hline Effects Test & Statistic & d.f. & Prob. \\
\hline \hline Cross-section F & 1.713732 & $(7.29)$ & 0.1449 \\
Cross-section Chi-square & 13.847266 & 7 & 0.0240 \\
\hline Sumber: Output Eviews 9.0 & & & \\
\hline
\end{tabular}

Sumber: Output Eviews 9.0

Berdasarkan hasil pengujian diatas dapat dilihat bahwa nilai Probabilitas (Prob). Crosssection F sebesar 0.1449 dan Cross-section Chisquare sebesar 0.0240. maka Ha ditolak dan $\mathrm{H}_{0}$ diterima. yang artinya Common Effect Model lebih tepat digunakan dibandingkan model fixed effect model.

\section{b. Hausman Test} berikut:

Hipotesis dalam Hausman test adalah sebagai

$\mathrm{H}_{0}$ : Model mengikuti random effect

$\mathrm{H}_{1}$ : Model mengikuti fixed effect

\begin{tabular}{|llll|}
\hline $\begin{array}{l}\text { Correlated Random Effects - Hausman Test } \\
\text { Equation: Untitled } \\
\text { Test cross-section random effects }\end{array}$ & & & \\
\hline \hline Test Summary & $\begin{array}{l}\text { Chi-Sq. } \\
\text { Statistic }\end{array}$ & Chi-Sq. d.f. & Prob. \\
\hline \hline Cross-section random & 8.272226 & 3 & 0.0407 \\
\hline
\end{tabular}

Sumber: Output Eviews 9.0
Berdasarkan hasil pengujian diatas dpat dilihat bahwa nilai Probabilitas (Prob) Crosssection random sebesar 0.0407. dimana angka tersebut lebih kecil dari $\alpha(0.05)$. maka dapat disimpulkan bahwa fixed effect model lebih layak digunakan dibandingkan random effect model.

\section{c. Lagrange Multiplier Test}

Hipotesis dalam Lagrange Multiplier Test adalah sebagai berikut:

$\mathrm{H}_{0}$ : Model mengikuti common effect

$\mathrm{H}_{1}$ : Model mengikuti random effect

\begin{tabular}{|c|c|c|c|}
\hline \multicolumn{4}{|c|}{$\begin{array}{l}\text { Lagrange Multiplier Tests for Random Effects } \\
\text { Null hypotheses: No effects } \\
\text { Alternative hypotheses: Two-sided (Breusch-Pagan) and one-sided } \\
\quad \text { (all others) alternatives }\end{array}$} \\
\hline & $\begin{array}{l}\text { Test Hypothesis } \\
\text { Cross-section }\end{array}$ & Time & Both \\
\hline Breusch-Pagan & $\begin{array}{l}0.906169 \\
(0.3411)\end{array}$ & $\begin{array}{l}0.511418 \\
(0.4745)\end{array}$ & $\begin{array}{l}1.417588 \\
(0.2338)\end{array}$ \\
\hline Honda & $\begin{array}{l}0.951929 \\
(0.1706)\end{array}$ & $\begin{array}{l}-0.715135 \\
-\end{array}$ & $\begin{array}{l}0.167439 \\
(0.4335)\end{array}$ \\
\hline King-Wu & $\begin{array}{l}0.951929 \\
(0.1706)\end{array}$ & $\begin{array}{l}-0.715135 \\
-\end{array}$ & $\begin{array}{l}0.003554 \\
(0.4986)\end{array}$ \\
\hline Standardized Honda & $\begin{array}{l}1.165468 \\
(0.1219)\end{array}$ & $\begin{array}{l}-0.327436 \\
-\end{array}$ & $\begin{array}{l}-2.626169 \\
-\end{array}$ \\
\hline Standardized King-Wu & $\begin{array}{l}1.165468 \\
(0.1219)\end{array}$ & $\begin{array}{l}-0.327436 \\
-\end{array}$ & $\begin{array}{l}-2.763904 \\
-\end{array}$ \\
\hline Gourierioux. et al.* & - & - & $\begin{array}{l}0.906169 \\
(>=0.10)\end{array}$ \\
\hline
\end{tabular}

Sumber: Output Eviews 9.0

bahwa nila1 probabilitas Cross-Section Breauschpagan sebesar 0.3411. dimana angka tersebut lebih besar dari $\alpha(0.05)$. maka dapat disimpulkan bahwa common effect model lebih layak digunakan dibandingkan random effect model.

\section{d. Kesimpulan Model}

\begin{tabular}{|c|l|c|c|}
\hline No. & \multicolumn{1}{|c|}{ Metode } & Pengujian & Hasil \\
\hline 1 & Uji Chow & CEM vs FEM & CEM \\
\hline 2 & Uji Hausman & REM vs FEM & FEM \\
\hline 3 & Uji Langrange Multiplier & CEM vs REM & CEM \\
\hline
\end{tabular}

Sumber: Output Eviews

Berdasarkan pengujian terhadap ketiga model regresi data panel, dapat disimpulkan bahwa Common Effect Model dalam regresi data panel digunakan lebih lanjut dalam mengestimasi pengaruh PAD, DAU, dan DAK terhadap Belanja Modal Pada Provinsi Banten periode 2011-2015.

\section{Uji Hipotesis}

a. Uji F 


\begin{tabular}{|lrll|}
\hline \hline R-squared & 0.659494 & Mean dependent var & 0.548750 \\
Adjusted R-squared & 0.631118 & S.D. dependent var & 1.082296 \\
S.E. of regression & 0.657340 & Akaike info criterion & 2.093407 \\
Sum squared resid & 15.55543 & Schwarz criterion & 2.262295 \\
Log likelihood & -37.86815 & Hannan-Quinn criter. & 2.154472 \\
F-statistic & 23.24164 & Durbin-Watson stat & 1.793980 \\
\cline { 2 - 2 } Prob(F-statistic) & 0.000000 & & \\
\cline { 2 - 3 } & & & \\
\hline \hline
\end{tabular}

Sumber: Output Eviews 9.0

Berdasarkan pada tabel diatas menunjukan bahwa nilai F-statistic sebesar 23.24164 sementara nilai $\mathrm{F}$ Tabel dengan tingkat $\alpha 5 \%$. df1 (k-1) = 3 dan df2 $(\mathrm{n}-\mathrm{k})=36$ didapat nilai $\mathrm{F}$ Tabel sebesar 2.86626. Dengan demikian F-statistic (23.24164) > F Tabel (2.86626) dan nilai Prob (F-statistic) sebesar $0.000000<\alpha(0.05)$ sehingga dapat disimpulkan bahwa Ha diterima. maka dengan demikian dapat disimpulkan bahwa variabel-variabel independen dalam penelitian yang terdiri dari PAD. DAU. dan DAK secara bersama-sama berpengaruh terhadap Belanja Modal (BM).

b. $\begin{aligned} & \text { Adjusted } \\
& \text { Determinasi) }\end{aligned}$
\begin{tabular}{|lrlr|}
\hline \multicolumn{1}{|c|}{ R-squared } & (Koefisien \\
\hline \hline R-squared & 0.659494 & Mean dependent var & 0.548750 \\
Adjusted R-squared & 0.631118 & S.D. dependent var & 1.082296 \\
S.E. of regression & 0.657340 & Akaike info criterion & 2.093407 \\
Sum squared resid & 15.55543 & Schwarz criterion & 2.262295 \\
Log likelihood & -37.86815 & Hannan-Quinn criter. & 2.154472 \\
F-statistic & 23.24164 & Durbin-Watson stat & 1.793980 \\
Prob(F-statistic) & 0.000000 & & \\
\hline \hline
\end{tabular}

Sumber: Output Eviews 9.0

Berdasarkan pada tabel diatas. dapat dilihat bahwa nilai Adjusted R - squared Sebesar 0.631118 yang berarti bahwa besarnya Belanja Modal dapat dijelaskan oleh PAD. DAU dan DAK sebesar 63.11 persen sementara sisanya yaitu sebesar 36.89 persen dijelaskan oleh variabel-variabel lain yang tidak diteliti dalam penelitian ini.

\section{c. Uji t}

\begin{tabular}{|c|c|c|c|c|}
\hline \multicolumn{5}{|c|}{$\begin{array}{l}\text { Dependent Variable: BM } \\
\text { Method: Panel Least Squares } \\
\text { Date: } 08 / 26 / 17 \text { Time: } 12: 15 \\
\text { Sample: } 20112015 \\
\text { Periods included: } 5 \\
\text { Cross-sections included: } 8 \\
\text { Total panel (balanced) observations: } 40\end{array}$} \\
\hline Variable & Coefficient & Std. Error & t-Statistic & Prob. \\
\hline c & 0.178698 & 0.149280 & 1.197073 & 0.2391 \\
\hline PAD & 0.224875 & 0.215366 & 1.044154 & 0.3034 \\
\hline DAU & 0.073647 & 0.008872 & 8.300621 & 0.0000 \\
\hline DAK & 0.341196 & 0.516178 & 0.661005 & 0.5128 \\
\hline
\end{tabular}

Sumber: Output Eviews 9.0
Berdasarkan pada tabel diatas menunjukan bahwa : 1. Nilai t-statistic PAD sebesar 1.044154 sementara t Tabel dengan tingkat $\alpha=5 \%$. df $(\mathrm{n}-\mathrm{k})=36$ didapat nilai $\mathrm{t}$ Tabel sebesar 1.68830. Dengan demikian bahwa t-statistic (1.044154) $<1.68830$ dan nilai Prob. $0.3034>0.05$ maka dapat disimpulkan bahwa variabel PAD dalam penelitian ini tidak memiliki pengaruh terhadap Belanja Modal. Maka dapat disimpulkan bahwa $\mathrm{H}_{1}$ dalam penelitian ini ditolak.

2. Nilai t-statistic DAU sebesar 8.300621 sementara t Tabel dengan tingkat $\alpha=5 \%$. df $(\mathrm{n}-\mathrm{k})=36$ didapat nilai $\mathrm{t}$ Tabel sebesar 1.68830 . Dengan demikian bahwa t-statistic (8.300621) $>1.68830$ dan nilai Prob. $0.0000>0.05$ maka dapat disimpulkan bahwa variabel DAU dalam penelitian ini memiliki pengaruh terhadap Belanja Modal. Maka dapat disimpulkan bahwa $\mathrm{H}_{2}$ dalam Penelitian ini diterima.

3. Nilai t-statistic DAK sebesar 0.661005 sementara $\mathrm{t}$ Tabel dengan tingkat $\alpha=5 \%$. df $(n-k)=36$ didapat nilai $\mathrm{t}$ Tabel sebesar 1.68830 . Dengan demikian bahwa t-statistic $(1.0661005)<1.68830$ dan nilai Prob. 0.5128 $>0.05$ maka dapat disimpulkan bahwa variabel DAK dalam penelitian ini tidak memiliki pengaruh terhadap Belanja Modal. Maka dapat disimpulkan bahwa $\mathbf{H}_{3}$ Dalam penelitian ini ditolak.Simpulan

\section{SIMPULAN}

Berdasarkan hasil analisis data yang telah dilakukan dan pembahasan mengenai hasil dari penelitian, maka kesimpulan dalam penelitian yang dilakukan ini adalah sebagai berikut :

1. Pendapatan Asli Daerah, Dana Alokasi Umum, dan Dana Alokasi Khusus secara bersama-sama berpengaruh terhadap Belanja Modal.

2. Variabel Pendapatan Asli Daerah (X1) dalam pengujian ini tidak memiliki pengaruh terhadap Belanja Modal karena kurangnya dalam menggali potensi daerah sebagai sumber penerimaan baru yang dapat dimanfaatkan secara berkelanjutan.

3. Variabel Dana Alokasi Umum (X2) dalam pengujian ini memiliki pengaruh terhadap Belanja Modal karena DAU merupakan salah satu transfer dari pemerintah pusat kepada 
pemerintah daerah yang dialokasikan untuk pemerataan kemampuan keuangan antar daerah untuk mendanai kebutuhan daerah dalam rangka desentralisasi.

3. Variabel Dana Alokasi Khusus (X3) dalam pengujian ini tidak memiliki pengaruh terhadap Belanja Modal karena dalam pembiyaan DAK tidak memerlukan biaya besar hanya bersifat khusus saja

\section{REFERENSI}

Ardhani Pungky. 2011, Pengaruh Pertumbuhan Ekonomi, Pendapatan Asli Daerah, Dana Alokasi Umum, Dana Alokasi Khusus Terhadap Pengalokasian Aggaran belanja Modal. Semarang : Universitas Diponegoro Semarang.

Bagus Ida. 2015, Pengaruh Dana Alokasi Umum, Dana Alokasi Khusus dan Pendapatan Asli Daerah Provinsi Bali. Bali : Universitas Udaya Bali.

Eksandy, Arry dan Freddy Heriyanto. (2017). Metode Penelitian Akuntansi dan Keuangan (Dilengkapi Analisis Regresi Data Panel dan Regresi Logistik Data Panel Menggunakan Program Eviews). Tangerang: Fakultas Ekonomi dan Bisnis Universitas Muhammadiyah Tangerang.

Gustiana Andi. 2016, Pendapatan Asli Daerah, Dana Alokasi Umum, Dan Belanja Modal terhadap Pertumbuhan Ekonomi. Makasar : Universitas Hasanuddin Makasar.

Gugus Arbie. 2013, Pengaruh Pendaptan Asli Daerah, Dana Alokasi Umum, Dana Alokasi Khusus, dan Dana Bagi Hasil terhadap pengalokasian Belanja Modal. Semarang : Universitas Negeri Semarang.

Hermawan, Achmad David. 2010, Pengaruh Pendapatan Asli Daerah, Dana Alokasi Umum, Dana Alokasi Khusus terhadap Pengalokasian Belanja Modal. Malang : Universitas Kanjuruan Malang.

Mardiasmo, 2002. Otonomi dan Manajemen Keuangan Daerah. Yogyakarta : Andi

Marzel Andreas. 2013, Pengaruh Dana Alokasi Khusus, Pendaptan Asli Daerah Terhadap Belanja Modal Pemerintah Kota Manado. Manado : Universitas Ratulangi Manado.
Permata Isti. 2016, Pengaruh Pendapatan Asli Daerah terhadap Belanja Modal pada Kabupaten/Kota Jawa Timur, Surabaya : STIE Surabaya.

Peraturan pemerintah (PP) Nomor 58 tahun 2005 tentang Pengelolaan Keuangan Daerah.

Priambudi Wimpi. 2016, Pengaruh Pendapatan Asli Daerah dan Dana Alokasi Umum terhadap Belanja Modal pada Kabupaten dari kota dipulau Jawa. Yogyakarta : Universitas Negeri Yogyakarta.

Rahayu Ayu. 2016, Pengaruh Pendapatan Asli Daerah, Dana Alokasi Umum, Dana Alokasi Khusus Terhadap Belanja Modal. Tangerang : Univesitas Muhammadiyah Tangerang.

Republik Indonesia. 2014, undang-undang no. 23 tahun 2014 tentang Pemerintah Daerah. Jakarta.

Republik Indonesia. 2009, Undang-undang no. 28 tahun 2009 tentang Pajak dan Retribusi Daerah. Jakarta.

Republik Indonesia. 2004, Undang-undang no 33 tahun 2004 tentang Pendapatan Asli Daerah. Jakarta

Sugiono. 2010, Metode Penelitian Kuantitatif Kualitatif. Bandung: Alfabeta.

Saragi. Juli Panglima. 2003. Desentralisasi Fiskal dan Keuangan Daerah dalam otonomi. Jakarta : Ghalia Indonesia.

Website www.bantenprov.go.id diakses pada 15 April 2017

Website www.lebakkab.go.id diakses pada 27 November 2017

Website www.pandeglangkab.go.id diakses pada 27 November 2017

Website www.bpkp.go.id diakses pada 27 November 2017

Website www.serangkab.go.id diakses pada 27 November 2017

Website http://tangerangkab.go.id diakses pada 29 November 2017

Website https://tangerangkab.bps.go.id diakses pada 29 November 2017

Website https://tangerangkab.bps.go.id diakses pada 29 November 2017

Website www.djpk.depkeu.go.id diakses pada 29 November 2017 
Website www.kompasiana.com diakses pada 7 Desember 2017

Website www.rocketmanajemen.com diakses pada 7 Desember 2017

Website http://www.kajianpustaka.com diakses pada 7 Desember 2017

Website https://id.wikipedia.org/wiki/Banten diakses pada 7 Desember 2017 